\title{
Socio-economic Situation of Poultry Farmer and the Local Chicken Production System of the East-Coast of Madagascar
}

\author{
Sendramampionona Rantenaina Ursule ${ }^{1,2, *}$, Hantanirina Herisoa Isabelle ${ }^{1}$, \\ Rabearimisa Rivo Nirina ${ }^{1}$, Zafitody Conscient ${ }^{2}$, Bola Aldiel ${ }^{2}$, Andriamananjara Andry ${ }^{3}$, \\ Randrianariveloseheno Arsène Jules ${ }^{1}$ \\ ${ }^{1}$ Higher School of Agronomic Sciences (ESSA), Animal Sciences, University of Antananarivo, Madagascar \\ ${ }^{2}$ Higher Institute of Technology of East Coast Regional (ISTRCE), Fénérive-Est, University of Toamasina, Madagascar \\ ${ }^{3}$ Radioisotops Laboratory (LRI), Antananarivo 101, Madagascar
}

Received July 20, 2020; Revised September 21, 2020; Accepted October 19, 2020

\begin{abstract}
Cite This Paper in the following Citation Styles
(a): [1] Sendramampionona Rantenaina Ursule, Hantanirina Herisoa Isabelle, Rabearimisa Rivo Nirina, Zafitody Conscient, Bola Aldiel, Andriamananjara Andry, Randrianariveloseheno Arsène Jules , "Socio-economic Situation of Poultry Farmer and the Local Chicken Production System of the East-Coast of Madagascar," Universal Journal of Agricultural Research, Vol. 8, No. 6, pp. 185 - 201, 2020. DOI: 10.13189/ujar.2020.080601.
\end{abstract}

(b): Sendramampionona Rantenaina Ursule, Hantanirina Herisoa Isabelle, Rabearimisa Rivo Nirina, Zafitody Conscient, Bola Aldiel, Andriamananjara Andry, Randrianariveloseheno Arsène Jules (2020). Socio-economic Situation of Poultry Farmer and the Local Chicken Production System of the East-Coast of Madagascar. Universal Journal of Agricultural Research, 8(6), 185 - 201. DOI: 10.13189/ujar.2020.080601.

Copyright $\bigcirc 2020$ by authors, all rights reserved. Authors agree that this article remains permanently open access under the terms of the Creative Commons Attribution License 4.0 International License

\begin{abstract}
Traditional family poultry farming is the most dominant in Madagascar, with $95 \%$ of farmers raising mostly local breed chickens. The objective of this study is to characterize the socio-economic aspect and the local poultry production system on the east coast of the large island. All 316 smallholder farmers with plus one adult chicken heads in the district of Fénérive-Est were included. Simple economic calculations were also made to assess the profitability of the poultry farm. The main results found that local chicken farming is an activity under the responsibility of men with an average age of $41.95 \pm 10.84$ years old. Most of these smallholder farmers are limited to the education level at secondary school (35\%) and primary school (34\%) level. On average, a household owns $22,89 \pm 23,14$ heads of local chickens. Livestock products are intended for sale (74 to $76 \%$ male and 37 to $40 \%$ female), self-consumption ( 3 to $5 \%$ male and $2 \%$ female) and socio-cultural events ( $12 \%$ male and 2 to $4 \%$ female). The losses due to diseases (more than 60\%), theft (23\%) and financing $(12.3 \%)$ were the main problems in chicken production system. However, traditional poultry production is beneficial to smallholder farmers with
\end{abstract}

$62.85 \%$ profit margin. Adequate research and a contribution from the State in this sector are essential to improve the living conditions of the farmers on the east coast of Madagascar.

Keywords Traditional, Poultry, Socio-economic, Production System, Farmers, East Coast, Madagascar

\section{Introduction}

Madagascar is a country with an agricultural vocation. The country has enormous agricultural potential in terms of the abundance of arable land, the existence of diversified agro-ecological systems allowing for diverse and varied agricultural activities for both crop and livestock production [1]. Nearly $80 \%$ of the population are peasants and derive most of their income from agricultural activities, which employ more than $75 \%$ of the rural labour force [2]. The agriculture sector ensures food and nutrition security at the national level, provides sufficient economic benefits for 
rural households and opportunities for non-farm employment through value addition. Agricultural development is a priority for the big island, as it could lift a large part of the rural population out of poverty. Unfortunately, this sector is involved in lower production and a large part of the rural population lives in poverty. The sector continues to suffer from a large-scale locust infestation, and successive cyclones, floods and droughts have exacerbated the socio-economic effects. In 2013, it was estimated that $92 \%$ of the population, or about 19 million people, were living on less than USD 2 per day. Gross domestic product per capita is lower than it was a decade ago, and food insecurity now affects about $20 \%$ of the population [3].

Among others, livestock play an important role in contributing to the income of $60 \%$ of Malagasy households. It also constitutes a first capital that can be mobilized for rural or peri-urban households, especially in times of hardship. This sector is dominated by dairy and poultry farming [4]. Poultry farming is practiced by $71.70 \%$ of households in Madagascar. It remains well represented with some 36 million heads for all chickens' species, $75 \%$ of which are local poultry production system [5]. At last decade poultry meat and egg production has increased steadily through the industrialization of poultry speculation, following the introduction of exotic race with high production such as, broilers and layers [6], village or family poultry farming system is the most dominant type of poultry farming in Madagascar, as in all African countries, and accounts for $95 \%$ of chickens in the extensive or traditional farming system. It is present throughout Madagascar's national territory, even in the most isolated regions, and is practiced mainly in rural areas where each poultry farming family keeps 7 to 20 heads of mixed chickens $[7,8]$. In the District of Fénérive-Est, poultry farming constitute $10.7 \%$ of the animal population as a $2^{\text {nd }}$ position after cattle population [9]. So, a question deserves to be addressed; how is the performance and the management in poultry farming production system in the eastern coastal zone of Madagascar? Therefore, the objectives of this study are to consider the socio-economic characteristics and to determine the local chicken production system. Two hypotheses must be verified and taken into consideration in this part. Firstly, local chicken farming on the east coast of Madagascar is very diversified on the agro-socio-economic aspect. Second, the production system of traditional Malagasy poultry farming faces multiple constraints.

\section{Materials and Methods}

\subsection{Study Area}

The most populated and most accessible rural communes in the District of Fénérive-Est were selected in this study. For example, Mahambo is located at $17^{\circ} 29^{\prime} 00^{\prime \prime}$ South and $49^{\circ} 28^{\prime} 00^{\prime \prime}$ East, Ambodimanga II is located between $17^{\circ} 20^{\prime} 45^{\prime \prime}$ South latitude and $49^{\circ} 21^{\prime} 35^{\prime \prime}$ East longitude and Ampasimbe Manantsatrana is located at $49^{\circ} 27^{\prime} 3^{\prime} 88$ East longitude and $17^{\circ} 8^{\prime} 28^{\prime} 15$ South latitude. Ampasimbe Manantsatrana is located in the extreme north of the District with a population of about 35,000 inhabitants spread over $242 \mathrm{~km}^{2}$ [10]. Mahambo is located in the extreme south of the District on the side of the national road number 5 with an area of $278 \mathrm{~km}^{2}$ and a population of 44,657 [11] and Ambodimanga II is among the rural commune which is in the north-central part of Fénérive-Est. It has 22,575 inhabitants over an area of 132 $\mathrm{km}^{2}[12]$. 


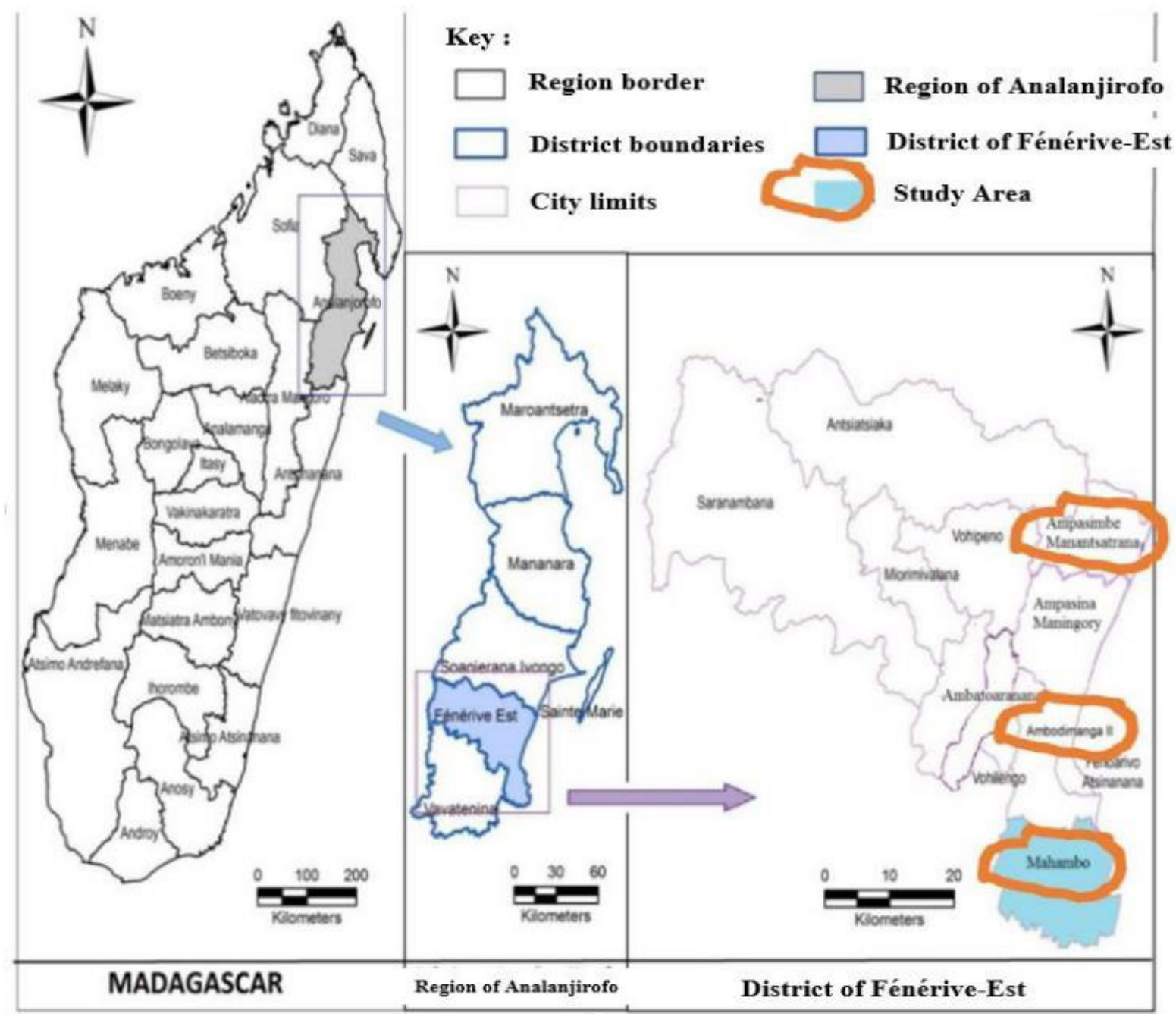

Figure 1. Location Map of the Study Area [13]

\subsection{Sampling}

The investigation focused exclusively on traditional poultry farming and semi-industrial or industrial poultry farms were not included. A total of 316 households with at least one adult chicken heads were surveyed. The spatial distribution of the respondents is as follows:

- 110 households in Ambodimanga II

- 92 breeders in Ampasimbe Manantsatrana

- 114 in Mahambo

These households are also chosen on the basis of sufficient distance to avoid the exchange of animals [14]. During the survey, in a village, if a repetition of answers to the questions is observed, the interviewer decides to stop it and changes village.

\subsection{Data Collection}

Using structured questionnaires in 3 pages, a survey sheet was prepared to facilitate the interview with the farmers. The descent was carried out during 3 months, between June and August 2018. The survey was based on the situation of livestock farming at time $\mathrm{T}$, using data from the rural commune. This said, defining a livestock system is a complex process because the establishment of a typology of livestock systems is a gradual and iterative process, so it will be necessary to conduct as many interviews as possible given the time, the means available and as many times as necessary to gather all the elements to describe and understand the choices in the management of animals and to evaluate the results. Ferraton and Touzard [15] even proposes the principle of triangulation, which requires at least 3 interviews per type of farming system. The sheet makes it easier to collect information on the farmer's intelligence, his or her husbandry, the farming system, the destination of the animals and the obstacles encountered by the farmers [14].

\subsection{Livestock Performances}

The sustainability of poultry farming depends mainly on the fertility of the hen, which is reflected in the ability to lay eggs and brooding, hence reproduction and production performance. The number of present breeding female 
chickens allows to know the information reproductive performance in normal year [15]. The main evaluation criteria in breeding chicken farming are :

Laying rate $=($ number of eggs laid $\mathrm{x} 100) /($ number of breeding hens $\mathrm{x}$ number of days)

Hatching rate $=($ number of eggs hatched $\mathrm{x} 100) /($ number of eggs incubated)

\subsection{Economic Parameters}

In order to know the economic benefits that the herder households receive through selling production following calculations [16]:

\section{- Cost of production}

Total expenditure $=$ construction costs + food costs + maintenance and processing costs + labour costs (3)

- $\quad$ Chicken returns

Number of chickens produced per year $=$ number of chickens sold + number of chickens consumed

Cost of chickens produced per year $=$ number of chickens produced $\mathrm{x}$ average price

Total income per year $=$ Cost of chickens produced per year + cost of eggs + cost of droppings

\section{- $\quad$ Profit Margin}

Annual Margin $=$ Total income - Total Expenditure (7)

\subsection{Data Analysis and Processing}

The survey forms were extracted and copied to a computer using Microsoft Excel. This enabled Excel to produce a table containing 30 columns (numbers of parameters collected) and 316 rows (numbers of households serviced), as well as the percentage, the curve and the graph. The quantitative data are processed with XLSTAT 2017.5.0 to describe and obtain the numerical characteristics of the herders. The software allows to calculate the mean, the standard deviation and the coefficient of variation.

\subsection{Methodological Limits}

First, like all rural communes in Madagascar, accessibility in some fokontany of the study area is very difficult. These circumstances had limited the number of fokontany visited in this study. Then, for a surveyed household, there was a constraint a time for discussion. Frequently, the dialogue continues during walking because the herder is in a hurry to get to the field. To respect the social hierarchy, some people avoid talking without the head of the household being present. The data collected is based on what the herders say. However, much of the information is unreliable and needs a lot of thought to understand it. The interviewer should cross-check beforehand to find out the truthfulness and reliability of the herders' answers. Another problem is the instability of the farmers' situation, both in terms of the number of animals they keep and the farming methods they use. Ferraton and Touzard [15] have already argued that the first methodological difficulty in studying family farming systems lies in the fact that livestock numbers are rarely stable and that variations seem at first glance to be fairly random. However, animal husbandry patterns have an internal consistency that we need to describe and understand. Thus, the questionnaires are not fixed and are not exhaustive. During the course of the survey, one should always expect to ask a lot of questions. It is not enough to rely on the observed image and the recorded information at time $\mathrm{T}$, because a system is not something fixed or permanent but evolving

\section{Results}

\subsection{Description of Mallholder Farmers}

\subsubsection{Responsible for breeding and age of breeders}

During this study, $89 \%$ of the people primarily responsible for the local breed of chicken farm were men (table 1). The $11 \%$ are women who are widows or single mothers.

Table 1. Primary animal husbandry manager

\begin{tabular}{ccccc}
\hline Sex & $\begin{array}{c}\text { Ambodimanga } \\
\text { II (\%) }\end{array}$ & $\begin{array}{c}\text { Ampasimbe } \\
(\%)\end{array}$ & $\begin{array}{c}\text { Mahambo } \\
(\%)\end{array}$ & $\begin{array}{c}\text { Total } \\
(\%)\end{array}$ \\
\hline Man & 91 & 85 & 91 & 89 \\
Woman & 9 & 15 & 9 & 11
\end{tabular}

According to the table 1, the majority of these first managers are head of households. In the District of Fénérive-Est, a household is composed of an average of 5 members and a recorded maximum of 12 members' commune of Ambodimanga II. The poultry farmers are aged very varied in each rural commune in the District of Fénérive-Est.

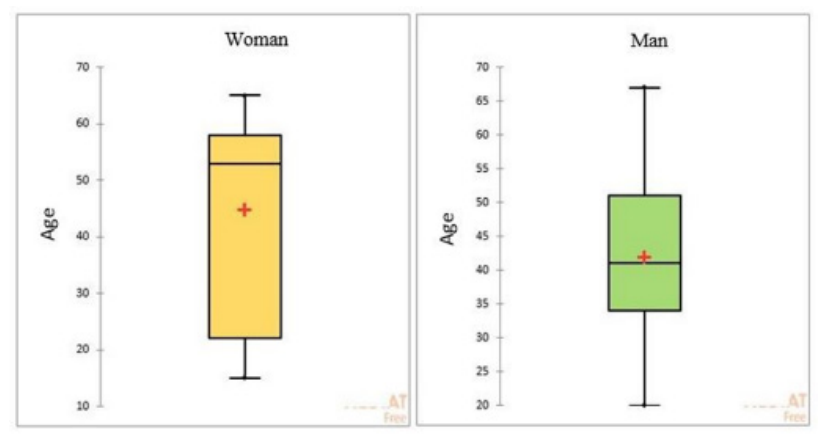

Figure 2. Age of traditional poultry farmers

According to this figure 2, responsible for poultry farming in rural Madagascar have an average age of 41.95 \pm 10.84 years for men is lower than women age with 44.69 
\pm 18.08 years. However, women are involved into poultry farming very early, with a minimum age of 15 years, compared to 22 years for men. The rural commune of Mahambo has younger poultry farmers than the other two communes, with an average age of 34.7 years for women and 41.60 years for men.

\subsubsection{Farmers education level and seniority}

In the east-coast of Madagascar, poultry farmers are involved in lower education level such as College and Primary. The following diagram provides more information on the educational level of these farmers.

Figure 3 shows that the level of schooling of rural poultry farmers. In fact, $35 \%$ of the farmers have completed their studies at college education level, 34\% at primary school level and $22 \%$ at secondary school level. Among other, academic level is lower with minor percentage (4\%) in Fénérive-Est District.
According to Figure 4, in each rural commune, illiterate smallholders are minor farmers with 5\%. Depending on the old responsible, farmers have been involved in local breeding chickens for 15 years $(1-45$ years $)$. The older the head of the household, the longer the year of practice.

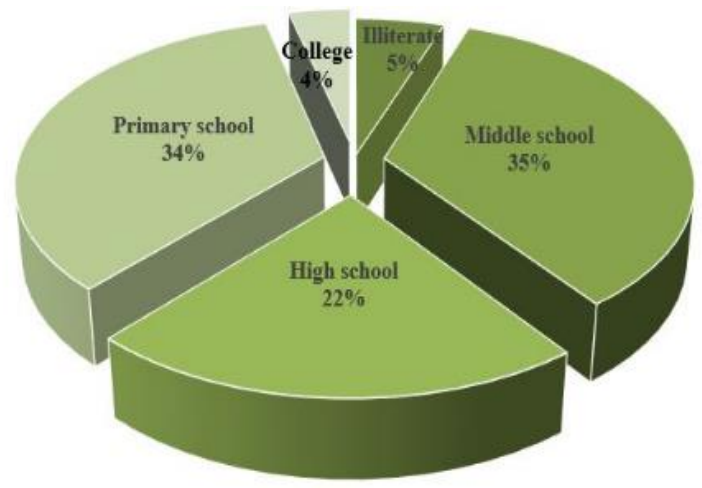

Figure 3. Level of education of poultry farmers

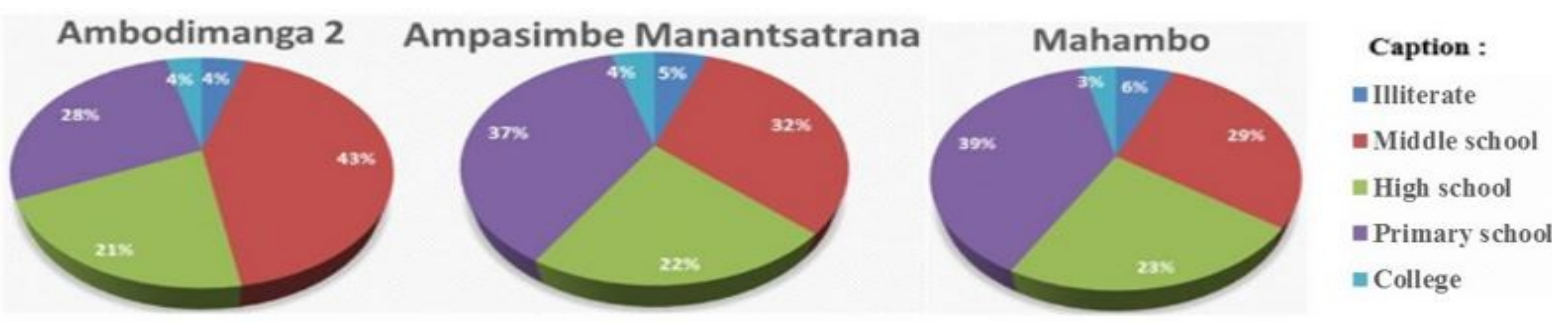

Figure 4. Level of schooling in the 3 rural communes

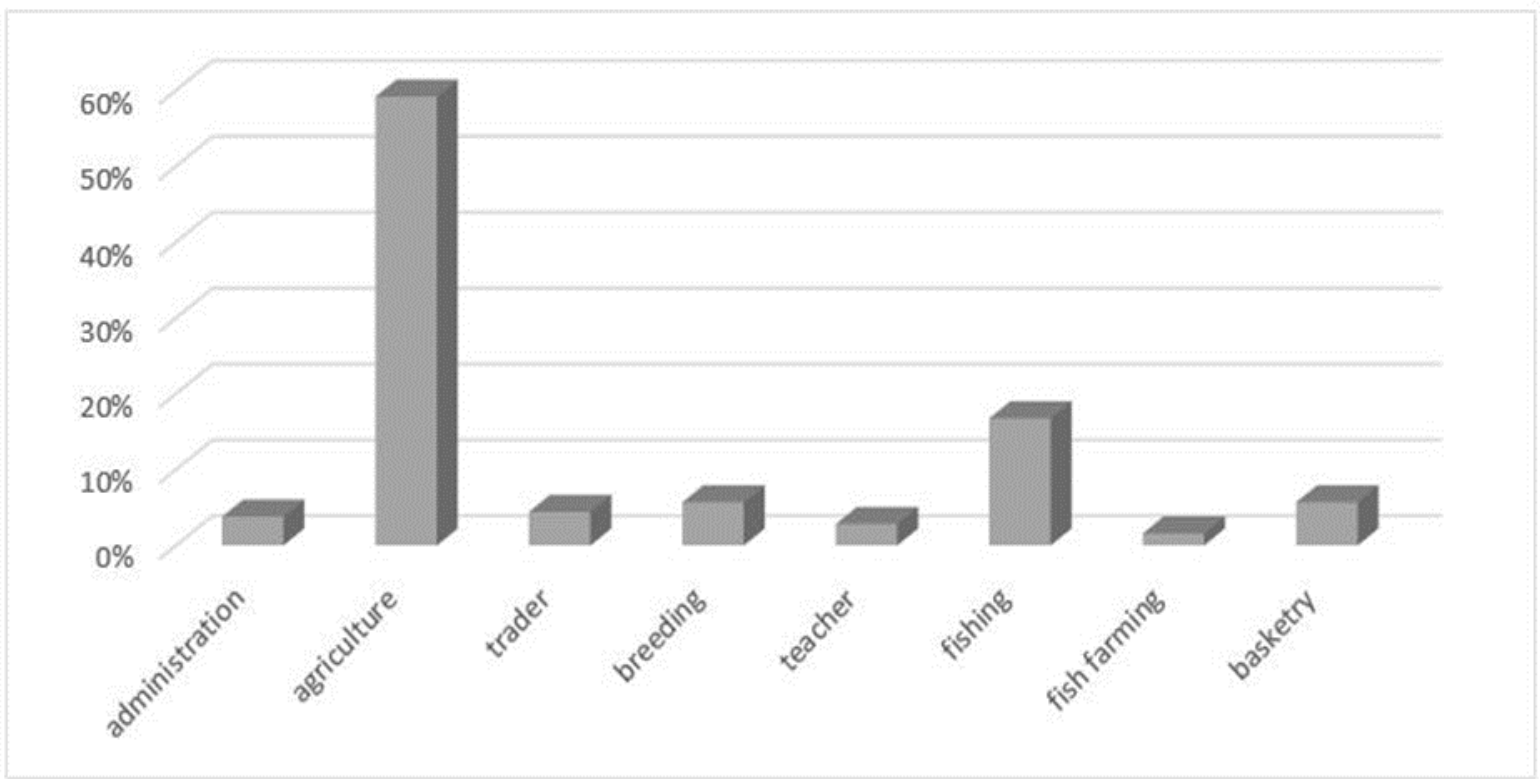

Figure 5. Main activity of indigenous chicken Farmers 


\subsubsection{Main Activity}

Over half of the poultry farmers in Fénérive-Est District considered this activity farming as a main occupation. However, there are some various priority activities of local chicken farmers.

According to this figure 5, after agriculture activity, with a $58 \%$, the most practiced activity is fishing with $17 \%$ of the population, because the District of Fénérive-Est is a coastal zone. A fewer smallholder farmer (6\%) occupied only local chicken in farms. Basketry, commerce, administration, education and fish farming hold a percentage of $6 \%, 4 \%, 4 \%, 3 \%$ and $2 \%$ respectively.

\subsubsection{Ethnic Group}

Lot of smallholder farmers are in Betsimisaraka ethnic groups.

As shown on figure 6, the demographic characteristics of the Fénérive-Est District are cosmopolitan with dominated proportions of Betsimisaraka ethnic group (87\%). The Merina and Betsileo ethnic are in second place with $6 \%$ and $3 \%$ of the population respectively. The remaining $3 \%$ represent the other tribes notably the Antandroy, the Antemoro, the Sakalava, the Sihanaka and so many others who are in minimal numbers.

\subsection{Characteristics of the Poultry Flock}

\subsubsection{Flock Size and Composition}

The local chicken flock on the East Coast of Madagascar is diverse. It is composed of different categories of chicken such as chicks, young chickens and adult males and females.

According to table 2, a family has a maximum of 181 chickens, composed of an average of 23 chickens consisting of 9 chicks, 7 young chickens, 3 adult females and 3 adult males for reproduction. A poultry farming family has at least one chicken and does not necessarily have all categories. The herd maximal size was higher with 181 heads in Mahabo than 92 heads in Ampasimbe. And the herd size was 155 heads in Ambodimanga. The following table shows the composition of the flocks in each rural community.

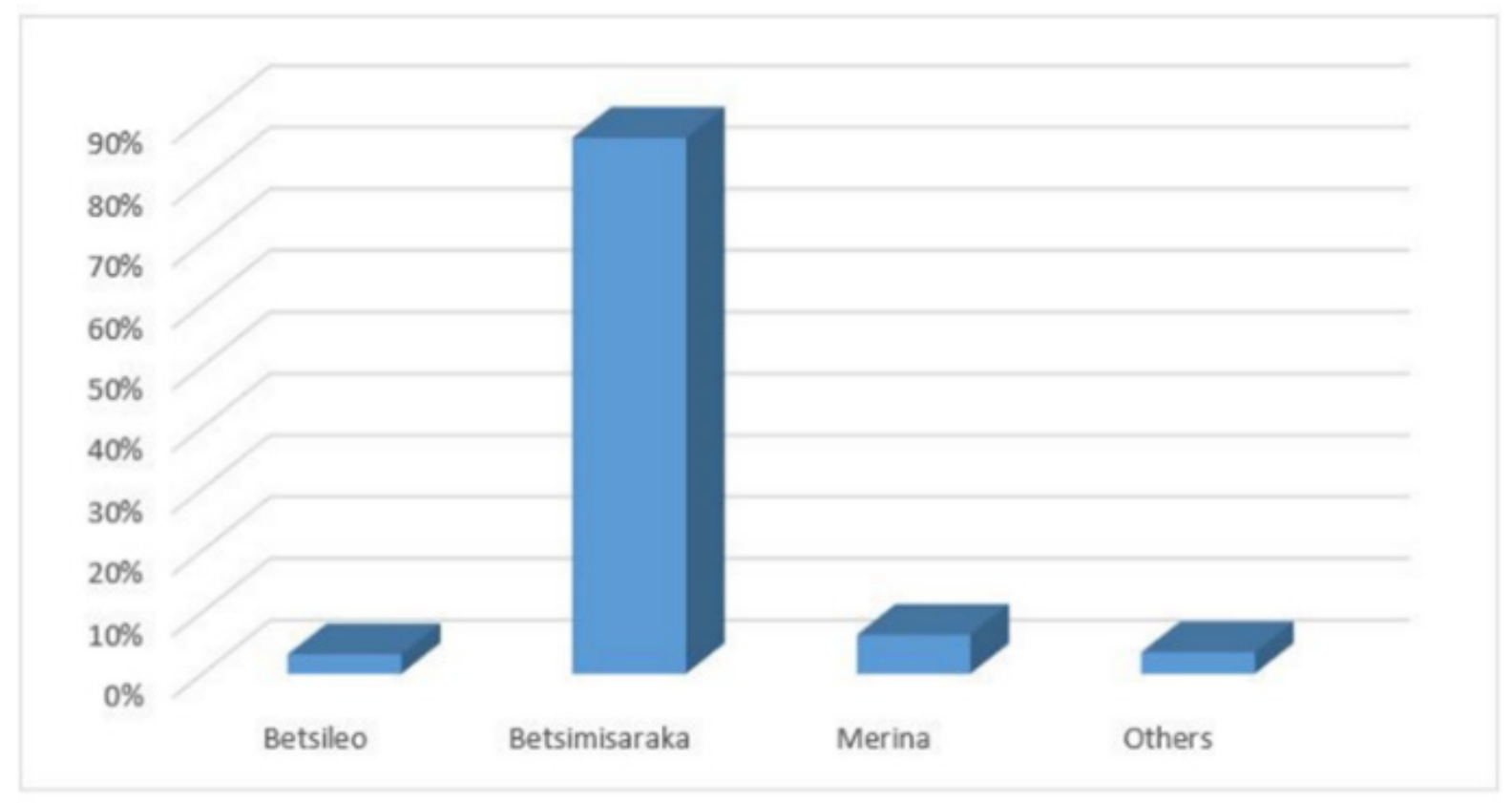

Figure 6. Ethnic group of traditional poultry farmers

Table 2. Composition of the local chicken flock

\begin{tabular}{cccc}
\hline Chicken Category & Maximum & Minimum & Average \pm sd \\
\hline Chicks & 75 & 0 & $9.20 \pm 11.81$ \\
Youth & 102 & 0 & $7.36 \pm 12.56$ \\
Adult Female & 35 & 1 & $3.17 \pm 3.38$ \\
Adult male & 31 & 1 & $3.17 \pm 4.68$ \\
Total & 181 & 1 & $22.90 \pm 23.14$ \\
\hline
\end{tabular}

Sd: standard deviation 
Table 3. Composition of livestock in the 3 rural communes

\begin{tabular}{|c|c|c|c|c|c|c|c|c|c|}
\hline & \multicolumn{3}{|c|}{$\begin{array}{c}\text { Ambodimanga } 2 \\
(\mathrm{n}=110)\end{array}$} & \multicolumn{3}{|c|}{$\begin{array}{l}\text { Ampasimbe } \\
(\mathrm{n}=92)\end{array}$} & \multicolumn{3}{|c|}{$\begin{array}{c}\text { Mahambo } \\
(\mathrm{n}=114)\end{array}$} \\
\hline & $\max$ & $\min$ & average \pm sd & $\max$ & $\min$ & average \pm sd & $\max$ & $\min$ & average \pm sd \\
\hline Chicks & 65 & 0 & $10.13 \pm 13.03$ & 45 & 0 & $7.97 \pm 9.36$ & 75 & 0 & $9.29 \pm 12.33$ \\
\hline Youth & 75 & 0 & $9.55 \pm 15.18$ & 42 & 0 & $5.09 \pm 7.70$ & 102 & 0 & $7.08 \pm 12.69$ \\
\hline Adult female & 35 & 1 & $3.49 \pm 4.05$ & 12 & 1 & $2.49 \pm 1.92$ & 25 & 1 & $3.41 \pm 3.53$ \\
\hline Adult male & 26 & 1 & $3.47 \pm 5.57$ & 18 & 1 & $2.53 \pm 3.34$ & 31 & 1 & $3.40 \pm 4.64$ \\
\hline Total & 155 & 1 & $26.64 \pm 27.35$ & 92 & 1 & $18.08 \pm 14.61$ & 181 & 2 & $23.18 \pm 23.80$ \\
\hline
\end{tabular}

Sd: standard deviation

According to table 3 , for the 3 zones surveyed during this study, the rural commune of Mahambo has a household with a large number of « gasy » chickens, with an average of 23 chickens per poultry farmer. Among others hand, the commune of Ampasimbe has fewer bird heads, with an average of 18 chicken heads per household.

It is rare to find in the majority of Malagasy rural households with only one kind of animal. Therefore, for traditional poultry farmers, they always associate their farms either with other types of poultry or with other animals. On the Malagasy East Coast, $65 \%$ of households associate the rearing of local breeds of chicken with ducks and other types of birds, $25 \%$ associate with zebu and $10 \%$ associate with at least 3 types of animals: pig farming, cattle farming and others (fish farming, other poultry species...).

\subsection{Local Chicken Farming}

\subsubsection{Type of Breeding}

The majority of farming were involved in open breeding with $90 \%$ of poultry farmers let their chickens out in the morning after giving them a few grains of maize or rice or kitchen scraps. At the end of each day, the chickens usually return to their respective nests. Each member of the family only watches whether the birds come in or not, and only checks the number of animals. The remaining $10 \%$ of the poultry farmers confine their chickens at home in poor habitats out of concern for the safety of their flocks.

\subsubsection{Habitat}

Most chickens habitats were found such as simple shelter on tree branches or on the roofs of the house or other dwellings.

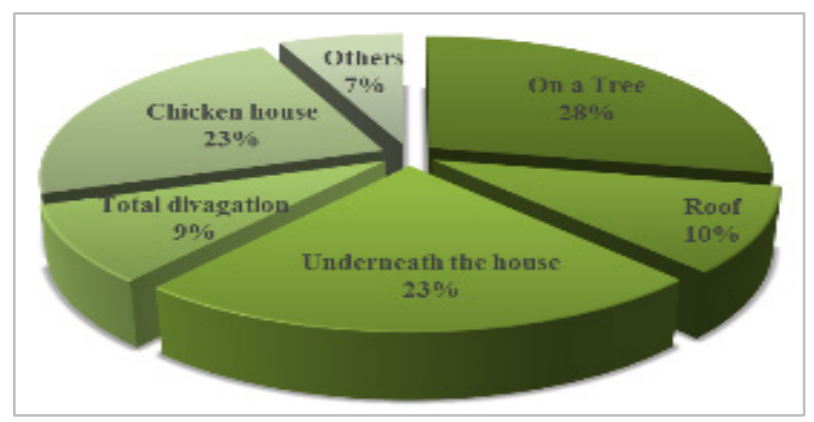

Figure 7. Type of housing for chickens
According to figure 7, 28\% of the farmers let their chickens sleep on top of a tree not far from their houses. $23 \%$ of them bring the animals under their house, a kind of ground floor in the shape of stilts, and $23 \%$ have home-made chicken houses built with local materials such as bamboo walls, dirt floors and ravenala leaf roofs. The henhouse is located close to the human habitation to ensure the safety of the animals. In addition, $10 \%$ of the poultry farmers let their birds sleep on the roof of their house or their neighbor's house, $9 \%$ let their animals ramble and do not know where their animals are sleeping, and $7 \%$ in other shelters, especially inside the farmer's house.

\subsubsection{Breeding Equipment}

The use of feeders and waterers differ from one rural community to another. The rambling system leads to the neglect of the use of breeding materials by the breeders. In the rural commune of Mahambo, $17.5 \%$ of poultry farmers use feeders compared to $12.7 \%$ in Ambodimanga II and $15.3 \%$ in Ampasimbe Manantsatrana. The feeders are of the traditional type and are built using out of local materials such as bamboo and wood. The percentage of use of water troughs is also very low, only $10 \%$ in Mahambo, $8.6 \%$ in Ampasimbe Manantsatrana and $7.1 \%$ in Ambodimanga II. For those who have them, water troughs are also made from local materials. Less than $2 \%$ of traditional poultry farmers use modern equipment because it is very expensive.

\subsubsection{Feeding}

$90 \%$ of the poultry farmers feed the birds twice a day, early in the morning before they go out for to walk and in the late afternoon before they come back home for those who know where their chickens are sheltered. In general, the type of feed given to local breed chickens is multiple. The feed changes from time to time in relation to the availability and scope of the breeders. Poultry farmers use frequently corn, rice bran, paddy, white rice, white rice, and all-purpose feeds such as kitchen scraps, tubers, fruits and herbs as a basis for feeding chicken.

According to Figure 8, corn is the most widely used feed base on the east coast of Madagascar. More than $50 \%$ of poultry farmers feed it to chickens, and $22 \%$ with white rice, especially for chicks and very young birds. More than $20 \%$ use fresh food (leftovers, fruits, vegetables...) for the birds. Other feeds such as rice bran, paddy and artisanal 
feed are used respectively $3.16 \%, 0.95 \%$ and $0.63 \%$ by the farmers. In 3 rural communes, corn is used by a large number of farmers. In Ambodimanga II, poultry farmers manufactured locally concentrates feed with local ingredients.

According to Figure 9, in the commune of Mahambo, paddy product isn't distributed for local chicken. However, there was multiple source feed in the District of Fénérive-Est. among others, local produced corn is partially distributed and some bought feed are also involved in feeding such as white rice, paddy and rice bran. In fact, lot of smallholders farmers' feed quantity isn't defined.

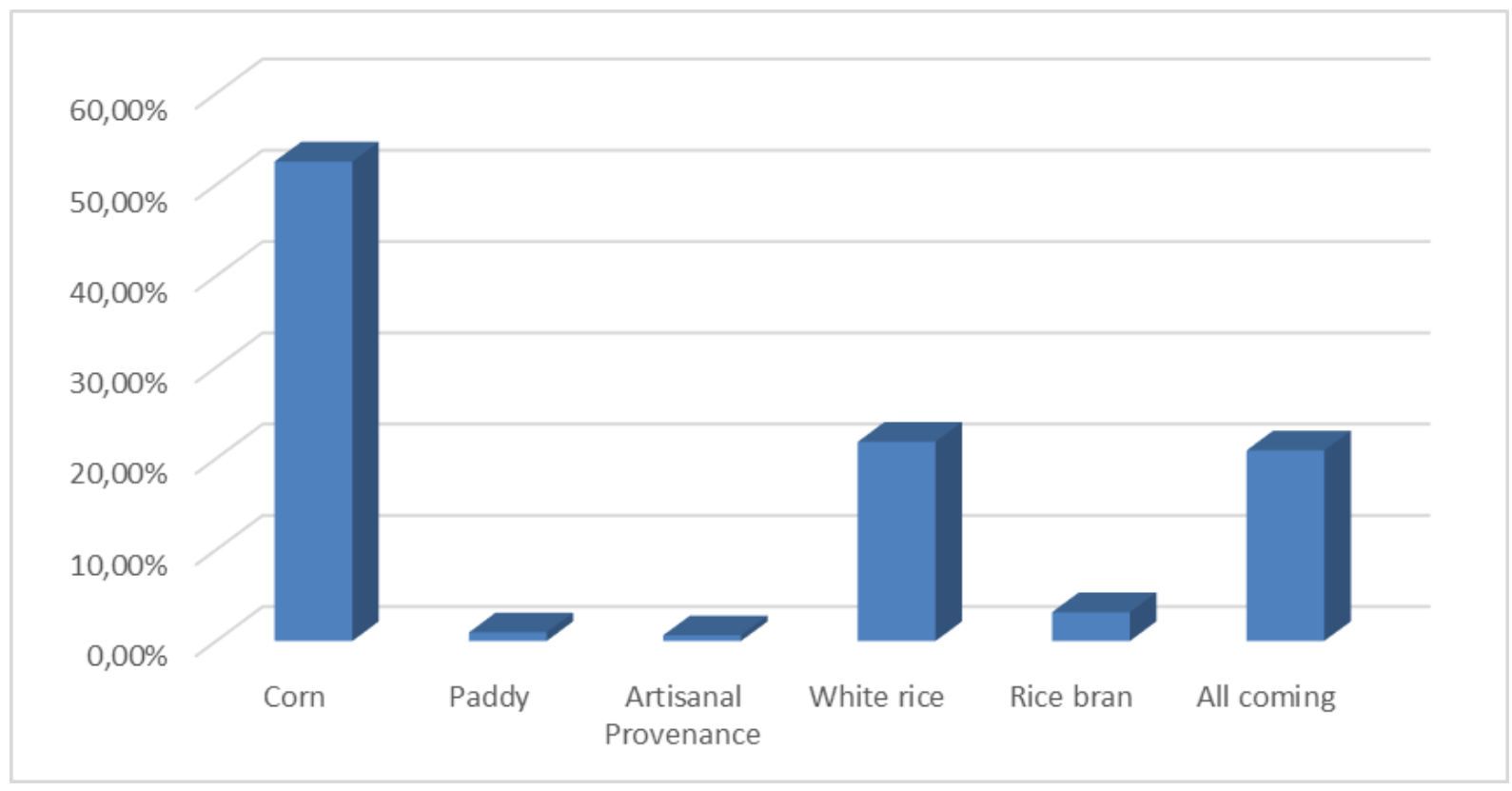

Figure 8. Basic feed for local chickens

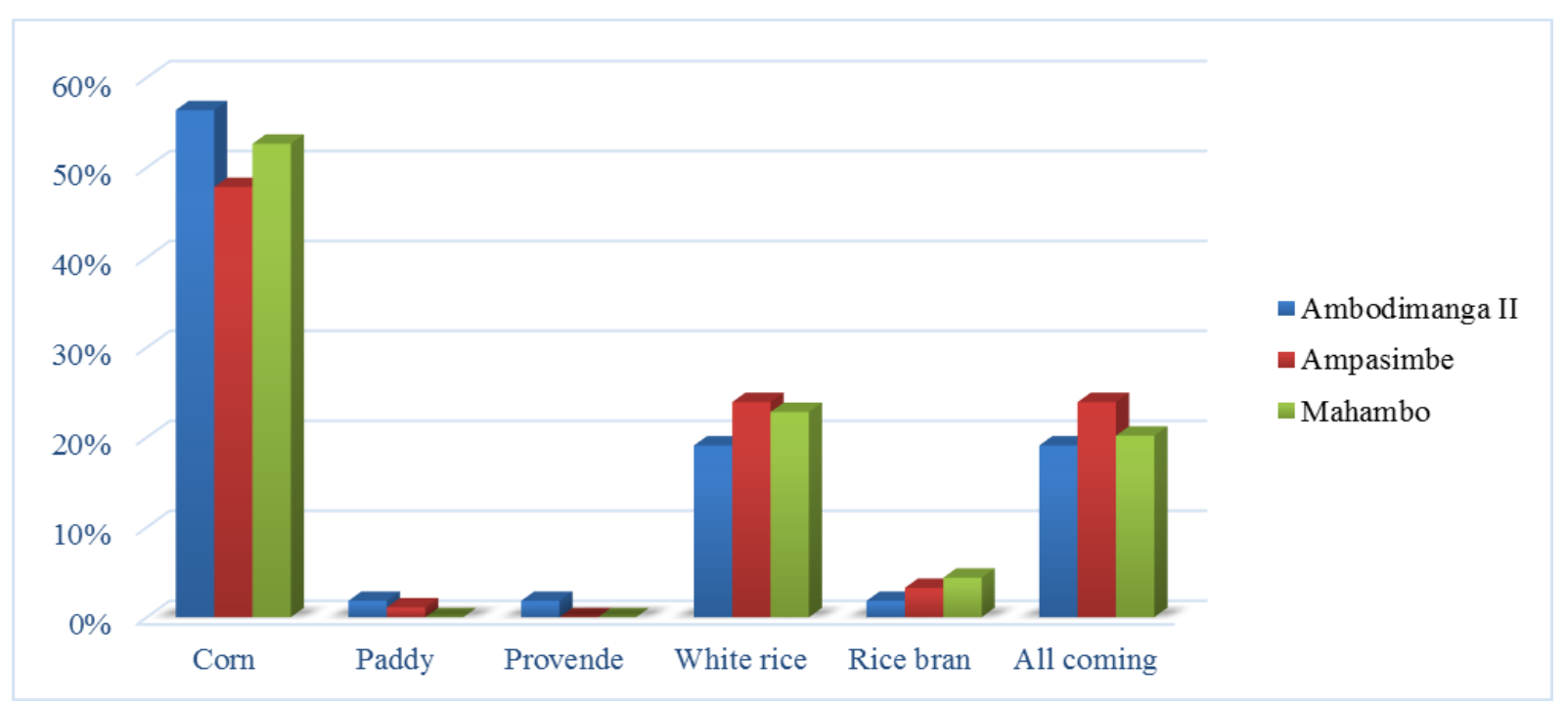

Figure 9. Type of food in each rural commune 


\subsubsection{Maintenance and Animal Health}

Less than $5 \%$ of poultry farmers are involved in chicken maintenance such as wing trimming, vitamin supplementation or wound treatment. However, the fighting cocks race benefit from some health occupations. Only $35 \%$ of farmers vaccinate their birds. The mortality rate of chickens in rural areas is very higher, especially in starting period, $51 \%$ for chicks and $43 \%$ for adult chickens in the south in Mahambo, $49 \%$ and $39 \%$ in the centre in Ambodimanga II, and $56 \%$ and $41 \%$ in the north in Ampasimbe Manantsatrana. Mortality is mainly caused by transmittable diseases, notably avian cholera and pseudo-fowl plague. These diseases affect the poultry flock more than twice a year, especially in the rainy season from January to March and from October to December, when microbial proliferation is at its peak.

For treatment, $68 \%$ of poultry farmers do not treat their sick chickens. They leave them to heal themselves or at worst they sell them on credit quickly to the neighbors, if there are many sick chickens, to be used for human food. Since these diseases are not zoonoses, farmers and customers have no hesitation in eating the affected chickens. The remaining $32 \%$ of the farmers treat their sick animals with traditional and natural medicines such as chili peppers. Some also give vitamins to strengthen the immune system of the chickens.

\subsection{Reproductive Performance}

\subsubsection{Selection of Breeding Males and Females}

The breeding system is very difficult to control in traditional poultry farming. Breeders select only $30 \%$ of the local breed of chicken to become breeders. These selections are mostly female. The males are largely destined for sale or to be a brood stock for the hens of neighboring breeders. Purchasing is the main source of breeding cocks. The sex ratio is 1 cock for 8 hens. The risk of crossbreeding between animals is very high. But, in general, as a consequence of raving, the males that mate with the hens are unknown sources.

\subsubsection{Egg-laying Rate}

In order to have the laying percentage, it is important to know the number of breeding hens, the number of eggs laid and the number of laying time.

According to this table 4, in the District of Fénérive-Est, each farmer has an average of 6 breeding hens but at most they have 13 . The number of eggs laid is 12 , carried out over approximately 14 days. The rural commune of Ambodimanga 2 has farmers with a higher average of 13 eggs laid but with 16 days of laying, a little longer. Therefore, after solving the equation, using the average figures, the laying rate on the east coast of Madagascar is : Egg-laying rate $=11.93 \times 100 / 6.16 \times 14.26$

The egg-laying rate of the local breed of chickens on the east coast of Madagascar is $13.57 \%$.

\subsubsection{Hatching Rate}

The hen of the local breed is renowned for its character of being a good incubator. To get the hatching rate, it is enough to know the number of eggs hatched and the number of eggs incubated. The formula below has to be solved:

Hatching rate $=$ number of eggs hatched (chicks) $\times 100 /$ number of eggs incubated

According to table 5, on average a hen incubates 11.33 eggs per brood, but at most it can incubate up to 22 eggs. On average, a hen can have 10.31 eggs hatched, but a maximum of 20 chicks after incubation. According to the formula hatching rate $=10.31 \times 100 / 11.32$, the hatching rate of the hen of the local breed of the east coast of Madagascar is $91.04 \%$.

Table 4. Number of breeding hens, eggs laid, day of laying in each rural commune

\begin{tabular}{cccccccccc}
\hline \multirow{2}{*}{ Rural commune } & \multicolumn{3}{c}{ Breeding hen } & \multicolumn{2}{c}{ Eggs laid } & \multicolumn{2}{c}{ Laying day } \\
& max & min & average \pm sd & max & min & average \pm sd & max & min & average \pm sd \\
\hline Ambodimanga II & 12 & 1 & $5.33 \pm 3.18$ & 22 & 6 & $13.08 \pm 4.37$ & 24 & 10 & $16.09 \pm 3.93$ \\
Ampasimbe & 12 & 2 & $6.83 \pm 2.75$ & 21 & 5 & $11.31 \pm 3.29$ & 23 & 8 & $13.39 \pm 3.06$ \\
Mahambo & 13 & 2 & $6.21 \pm 3.09$ & 23 & 7 & $11.75 \pm 3.54$ & 23 & 10 & $13.88 \pm 3.44$ \\
Total & 13 & 1 & $6.16 \pm 3.00$ & 23 & 5 & $11.93 \pm 3.73$ & 24 & 8 & $14.26 \pm 3.53$ \\
\hline
\end{tabular}

$\mathrm{Sd}$ : standard deviation

Table 5. Number of incubated and hatched eggs in the District of Fénérive-Est

\begin{tabular}{ccccccc}
\hline Rural commune & \multicolumn{3}{c}{ Incubated eggs } & \multicolumn{3}{c}{ Hatching eggs } \\
& max & min & average \pm sd & max & min & average \pm sd \\
\hline Ambodimanga II & 22 & 6 & $12.17 \pm 4.10$ & 20 & 5 & $10.71 \pm 3.62$ \\
Ampasimbe Manantsatrana & 20 & 5 & $11.00 \pm 2.97$ & 17 & 5 & $10.03 \pm 2.52$ \\
Mahambo & 18 & 5 & $11.292 \pm 3.11$ & 16 & 5 & $10.25 \pm 2.74$ \\
Total & 22 & 5 & $11.33 \pm 3.37$ & 20 & 5 & $10.31 \pm 2.93$ \\
\hline
\end{tabular}

Sd: standard deviation 


\subsection{Destination and Marketing of Production}

\subsubsection{Destination of the Products}

For farmers, chickens are classified as adults from the 6th month of age. Indeed, it is from this moment that a rational valorisation of the flock is likely. The chickens are destined either for live sale, for self-consumption, for breeding, or to be used for social events.

According to this table 6, about 74 to $76 \%$ of the cocks are intended for sale alive in the 3 rural communes of the district of Fénérive-Est against 37 to $40 \%$ for females. The rate of chickens intended for breeding is in favour of females. More than $50 \%$ of the hens are reserved for the regeneration of the poultry flock. Other destinations including self-consumption and social events are in favour of the rooster (about 13\%). Self-consumed females are less than $3 \%$ of the total flock. Social events are made up of habits and customs, sacrifices, gifts for new-borns, fighting males. The chickens used for these events are rarely females.

\subsubsection{Marketing}

According to the same Table 6, for chickens intended for live sales. The sales system is very specific. $86 \%$ of traditional poultry farmers deliver their chickens to collectors who are the actual sellers in this system. Few farmers sell their chickens directly. The animals are sold on the local market (14.2\%), along the national road (31.5\%) and the majority are transported to the neighbouring town (54.3\%), particularly Fénérive-Est, Toamasina and sometimes to the capital.

The selling price depends, in more than $85 \%$ of cases, on the size of the chicken to be sold. The weight of the chickens is estimated on the ground by holding them on hand. Eventually, it depends on the place of sale, as chickens sold in the city are more expensive than those sold locally. The price depends on the time and period of the sale, chickens sold during feasts are more expensive than daily. But, rarely, the price also depends on the type of customer and the number of chicken heads bought. The price of an adult chicken, weighty $800 \mathrm{~g}$ to $2 \mathrm{~kg}$, varies between 10,000 to $30,000 \mathrm{Ar}$ (2.5 to 7.5 Euro). Roosters are more expensive than females. The eggs of the local hens are generally intended for brooding and are only sold exceptionally during the lean season at a price similar to the price of eggs of about $500 \operatorname{Ar}(0.125$ Euro).

\subsection{Economic Aspect of Local Chicken Farming}

In order to assess the economics of rearing the local breed of chicken in a traditional system, it is necessary to calculate the cost of production, the total revenue and the profit margin over one year.

According to tables 3 and $6,75 \%$ and $37 \%$ respectively of the roosters and hens are sold; $3.3 \%$ of the roosters and $2.5 \%$ of the hens are consumed. Thus, table 7 above shows that with an average of 23 chicken heads per farmer, 13 are sold and 2 are consumed.

\subsubsection{Cost of Production}

The burden of chicken production in a traditional chicken farm is minimal. It includes the costs of building poultry houses, purchasing rearing equipment, maintenance and processing costs, labour costs and, above all, feed costs. This cost varies greatly from one farm to another. According to the survey of farmers and after a simple calculation, the average annual production cost of a local chicken farmer is 98,225 $\pm 44,220$ Ariary (24.56 \pm 11.055 Euro) (Table 7).

Table 6. Destination of local breed chickens

\begin{tabular}{ccccccccc}
\hline & \multicolumn{2}{c}{ Live sales (\%) } & \multicolumn{2}{c}{ Reproduction (\%) } & \multicolumn{2}{c}{ Self-consumption (\%) } & \multicolumn{2}{c}{ Social facts (\%) } \\
Rural commune & Male & Female & Male & Female & Male & Female & Male & Female \\
\hline Ambodimanga II & 76.2 & 39.6 & 7.6 & 53.7 & 3.3 & 2.5 & 12.9 & 4.2 \\
Ampasimbe & 74.2 & 37.1 & 8.2 & 58.9 & 5.1 & 2.3 & 12.5 & 1.7 \\
Mahambo & 75.3 & 38.2 & 7.9 & 55.3 & 4.6 & 1.9 & 12.2 & 4.6 \\
\hline
\end{tabular}

Table 7. Expenditure, revenue and operating profit per year

\begin{tabular}{ccccc}
\hline Parameters & Average \pm sd & Min & Max & CV $(\%)$ \\
\hline Number of chickens sold & $13 \pm 7$ & 1 & 72 & 53.84 \\
Number of chickens consumed & $2 \pm 0.82$ & 0 & 8 & 41.00 \\
Price of a chicken (Ar) & $16,750 \pm 7,230$ & 8,500 & 30,000 & 43.16 \\
Production cost (Ar) & $98,225 \pm 44,220$ & 62,500 & $1,153,500$ & 45.01 \\
Recipe (Ar) & $253,000 \pm 118,250$ & 196,000 & $3,615,000$ & 46.73 \\
Profit margin & $155,000 \pm 97,420$ & 135,200 & $2,563,000$ & 62.85 \\
\hline
\end{tabular}

$\mathrm{Sd}$ : sdandard deviation; $\mathrm{CV}$ : coefficient of variation 


\subsubsection{Chicken Returns}

Through the live sale of chickens and possibly eggs and droppings, a farmer can have an average annual income of $253,000 \pm 118,250$ Ariary $(63.25 \pm 29.56$ Euro). For a farmer who owns and sells many more chicken heads, he can generate up to $3,615,000$ Ariary (903.75 Euro) of income per year. However, a traditional poultry farmer has at least 196,000 Ariary (49 Euro) of income per year (Table 7).

\subsubsection{Profit Margin}

Currently, in the district of Fénérive-Est, a local breed chicken farmer who sells less than 2 chickens per month generates a net profit of 135,200 Ariary (33.8 Euro). For those who sell a maximum of chicken heads, they can have an income of 2,563,000 Ariary (640.75 Euro) per year. Therefore, according to Table 7, a farmer can obtain an average profit margin of $155,000 \pm 97,420$ Ariary $(38.75 \pm$ 24.355 Euro) by selling the chickens, eggs and droppings.

\subsection{Main Constraints in Traditional Poultry Farming}

\subsubsection{Social Problems}

In traditional and family poultry farming, the social problem is one of the major obstacles in the development of the sector. Social pressure constitutes $23 \%$ of the problems encountered by poultry farmers. It includes insecurity $(13 \%)$, chicken theft is very frequent in rural areas, and taboos in relation to customs, habits and religions (4\%) prevent farmers from expanding their operations. In addition to all this, farmers face a lack of training $(6 \%)$, many farmers have received no instruction before entering the local chicken industry.

\subsubsection{Technical Problems}

The vast majority of constraints faced by poultry farmers are based on this technical part. The technical problem occupies $64.7 \%$ of the obstacles to local chicken farming. It is composed of $38 \%$ by the epidemic diseases that attack chickens. In the District of Fénérive-Est, chickens are struck by avian cholera and Newcastle twice a year. The resulting damage is catastrophic and causes a total annihilation of the local poultry flock. All this is compounded by the damage caused by predators such as rats and snakes that attack the chickens, especially at an early age. In addition, the farmers also suffer problems with $19 \%$ of their feed. Feed is not available all year round. Controlling the quantity and quality of feed is not easy for farmers. Moreover, the inbreeding of the animals adds to these technical problems at $7.7 \%$ which lead to a decrease in production. Reproduction is very difficult to control for poultry farmers.

\subsubsection{Financial Constraints}

This problem is especially faced by farmers who make a lot of investment in local chicken farming. It constitutes $12.3 \%$ of the constraint encountered by traditional poultry farming. It is mainly linked to (i) the difficulty of accessing rural financing, (ii) the complication of the procedure for accessing rural credit, and (iii) the lack of State financial support for the sector.

\section{Discussions}

\subsection{Influences of Farmers' Characteristics on Their Farming Behavior}

Traditional and family poultry farming in the District of Fénérive-Est is an activity that is mostly carried out by men rather than women. This has also been suggested by similar studies in Burkina Faso [17], in the East of the Democratic Republic of Congo, where more than $60 \%$ of men are primarily responsible for raising local chickens [18] and confirmed by a previous study in the same country [19]. This male predominance is due to social considerations that men are the decision-makers in Malagasy households, a case generally observed in African countries [14,20-23]. Sometimes also, men insisted on answering questions during the survey to avoid women's contact with visitors $[24,25]$. However, contrary to studies conducted in the central zones of Madagascar, traditional poultry farming is an activity that is more than $75 \%$ reserved for women and children in Moramanga [6,26]. Similar to those noted by various authors from other African countries that women and children are mainly concerned by family poultry farming [27,28] particularly in Algeria at 73\% [29], in Togo [30], in Congo [31], in Cameroon [32,33], Senegal [34,35], Benin [36]. This situation explains why the entry of men into the production circuit is not so necessary given that the financial profits of traditional poultry farming is very low [33]. Women and children are the most vulnerable groups in Africa and are the first beneficiaries of the use of animal products [25].

The age of farmers involved in livestock farming proves that local chicken farming requires maturity and commitment by its leaders. Traditional poultry farming mainly concerns people over 40 years of age [17]. In Algeria, the average age of farmers is 45 years [29]. It is from this age that a person is considered truly adult and responsible. Indeed, it is obvious for a responsible person to find complementary activities to strengthen the household income. Poultry farming, which for the Malagasy on the east coast was a secondary activity as is the case in most African countries [14].

Despite the presence of illiterate poultry farmers on the big island, the schooling rate is higher compared to farmers than in Cameroon, where more than $50 \%$ of the farmers do not even have a primary school certificate [25]; in Benin and southern Kenya, where more than $59 \%$ of farmers are illiterate [36,37]; in northern Ethiopia, where the illiteracy 
rate is $82.12 \%$ [38]. The schooling rate of the herders in this study is similar to that of rabbit farmers in Amoron'i Mania region [39]. This explains why the breeders in Madagascar are rural people who do not have access to better training. The illiterate people encountered in the ranks of traditional poultry farmers show that traditional poultry farming is typically a village activity that serves as a means of sustenance for poor families [18]. Chabi Toko [36] had argued that this low level of schooling may be due to the fact that raising local chickens requires little investment. In order to improve the local chicken production system, it is essential to increase education at rural level.

A breeder's experience also depends on his age. The older he is, the more years of experience he has in poultry farming. More than $50 \%$ of households on the east coast of Madagascar have 15 years of experience raising local breed chickens. The same trend was found by a study of traditional poultry farmers in the Democratic Republic of Congo and Chad that their poultry farmers have more than 10 years of experience $[19,40]$.

The District of Fénérive-Est is renowned for its wealth of cash crops, particularly cloves and vanilla. It is logical that more than $50 \%$ of the population is involved in agriculture. In Cameroon, food crops and cash crops are also the first farmers occupation because they meet the daily food needs of the family [25]. The same observation also applies in DRC, Chad and various African countries, confirming that the main activity of rural Africans is agriculture [19]. Yet, traditional chicken farming could be an opportunity to fight against lack of appropriate nutrition and lack of income of rural households $[25,27,28]$.

Indigenous chicken farmers in the rural commune in the centre and south of Fénérive-Est District have a larger livestock size than those in the rural commune in the south. The average size of chicken flock in Fénérive-Est District is much higher than the national average of 11 Malagasy chicken heads per farmer [41,42]. However, it corroborates to what is found in Vatomandry District which is in the same province as Fénérive-Est [43]. Internationally, this chicken flock size is similar to that of Benin [36] and DRC [18], where each household raises an average of 24 chickens, but is much higher in several African countries, notably in Cameroon $[33,44]$ where the average is 10 chickens per farmer, in Kenya with an average of 6.7 chickens per farm [45] and in Senegal [35]. The size of flocks in African villages varies from 5 to 20 birds per farm $[46,47]$. However, this size is lower than what is found in Burkina Faso with more than 33 chickens per farmer $[17,48]$, in Algeria with 31 chickens per farm [29], and in Vietnam (Nguyen, 2016) finding 31.87 chickens per household. For the composition of the chicken flock, the number of chicks is mostly higher than other categories of animals. This finding is similar to those found in Vietnam in a study with local breeds of chickens called Ho that chicks are twice the numbers of adults [49]; same case in Benin noting 657 chicks against 493 adult chickens and
117 roosters [36]. The chicks are the future of the farm, whereas the adult males are destined for sale, that is why they are the least numerous in the flock [14].

\subsection{System for Breeding Malagasy Local Poultry}

The extensive rambling or semi rambling system is the main mode of traditional and family poultry farming on the east coast of Madagascar. The traditional system is characterized by the free-range extensive type to enrich their feed, which must be excavated in the wild $[48,50,51]$. This same trend has been observed throughout the local chicken farming in the African continent, particularly in Cameroon where $80 \%$ of the poultry farmers leave their chickens raving [14,25]; in Algeria, 18.8\% of the farms are free-range and $77.1 \%$ are semi-released [52], in Nigeria, saying that in rural areas birds are wandering all day long to manage to find most of their daily portion [53]; in Congo Brazzaville [31], in DRC finding $94.17 \%$ of the local chicken farm is unconfined [18], and in many other countries. Birds have to ramble to supplement their feed with animal protein provided by earthworms, insects and other dead animals of all kinds [44].

This system of free-range farming of local chickens leads to habitat neglect. In the District of Fénérive-Est, not even a quarter of the farmers own chicken houses. Similarly in Cameroon, the chicken house is built with local materials for $32 \%$ of the farms, while for the rest, the chickens sleep either in the human habitation hut (34\%) or outside (34\%) [33]. In the absence of housing, they perch on tree branches and/or rest on the house roofs [25]. This situation is found in almost all countries that adopt traditional and family poultry farming, such as the one observed in the DRC, where chickens'lodges are often made of clay and covered with wood, dried plants and metal sheets, or wooden and wire mesh cages placed in a corner of the main room of the house [19,54], 81.11\% of farmers do not have specific housing for chickens, but they use their own house or kitchen to shelter the chickens, some of them spending the night under trees [18]; the same is observed in Algeria [52]. However, in Burkina Faso, the birds' habitat is structured according to the production system; chicks and young are generally raised in a large hut with a thatched roof; $84 \%$ of farmers have a traditional henhouse in the form of a hut, $6.67 \%$ have shell henhouses made of straw, while $9.33 \%$ do not, and the birds spend the night perched on trees [17]. Different species of poultry are generally mixed together in the same henhouse $[48,55,56]$. This situation further increases the loss of chickens by predators and various weather conditions, resulting in a loss of farmers income [44].

Livestock farmers are not enthusiastic about using livestock equipment because traditional poultry farming remains a secondary activity for farmers $[18,57]$. Food is distributed on the ground because the equipment is almost non-existent $[17,33]$. In a study conducted in Cameroon, Fotsa [14] had argued that neglect in the use of livestock 
equipment may be due to the very low schooling rate and poverty of pastoralist farmers who cannot afford too expensive modern equipment.

There is no rationing plan for several herders, they distribute each according to their will in the morning and in the evening [18]. This is a reality in several African countries. In Togo, the chicken in family farms seeks its own food [30], while in Senegal $65.4 \%$ of the breeders give importance to distribute a millet food supplement distributed daily to the chickens in the order of 1 to 3 handshakes [35]. Similarly in DRC, chicken feeding is rudimentary and little monitored; no rational system is practiced, the poultry wanders in the wild and feeds on leftovers from meals, crop residues that it picks up in the vicinity of houses or around fields, granaries and cereal threshing areas as was observed in Guinea [58]; only $10.4 \%$ give a compound feed to the birds [19,54].

The majority of the poultry farmers in this study neglects the health aspect of the chickens. Farmers invest almost nothing but rely on the animal's hardiness, resistance to certain diseases and ability to live in extensive farming systems with few inputs $[33,49]$. In the event of diseases, livestock farmers use traditional treatment. This situation is encountered in almost all similar studies especially in Africa, particularly in Cameroon mentioning that diseases are the causes of considerable mortality in chickens [32]; in Algeria recording $33.8 \%$ of bird losses are caused by pathology [52], in Mali revealing that their poultry pay a heavy price of disease each year [57] and in DRC mentioning that epidemics of the disease $(82.78 \%)$ is the main factor in the decline of adult chickens and that Newcastle disease (Avian Pseudopest) is the most frequent in these farms [18]; this was also observed in Cameroon [59]. Traditional treatment is also encountered in Cameroon expressing that herders use plants such as Kalanchoe crenata against coccidiosis, Carica papaya leaves against diarrea and Piper guineense pepper against cough [33]; in Senegal [59], and also in DRC noting that traditional treatment is the practice used as a battle horse for care in these herds [18]. This traditional remedy could amortize the costs of treatment in rural areas and reduce the heavy price paid by local chickens in wandering village conditions. The national vaccination rate is very low, it was confirmed during a study on chickens in Vatomandry showing that it is only $4.9 \%$ for Newcastle disease [8] and a study in Manandriana (Region of Amoron'i Mania) finding $60 \%$ of poultry farmers who neglect vaccination [60]. This national vaccination rate remains very low compared to that found in Senegal where rural poultry farmers have never vaccinated their poultry for the $32 \%$ of farmers $[61,62]$. Ignorance, carelessness and lack of mastery of the vaccination technic are the main reasons for farmers not to do so [32].

\subsection{Reproduction and Production Performance of Family Poultry Farming}

Breeding is difficult to control by the farmers in the
Fénérive-Est District. It is not controlled because of the frequentation between males and females, an opinion affirmed by a study on poultry farming carried out in Benin [36] and Togo [63]. In the Democratic Republic of Congo, more than $70 \%$ of breeders do not select breeding stock [18], the cocks used in breeding have diverse origins [19] which confirms the results found by this research. Inbreeding is the serious consequence of this lack of control over reproduction [49]. Mahammi [52] had argued in his study of local chicken rearing systems in western Algeria that this can be avoided through the implementation of management plans and genetic selection. The majority of breeding cocks are purchased, also following a pattern found in Cameroon at 85\% [33] and in DRC at $45.8 \%$ of the farmers who supply the cocks to the market [19]. The number of hens for one cock (sex ratio) is much higher than that found in Cameroon, where 1 cock for every 3.15 hens is registered [33], with Burkina Faso noting a male/female ratio of $1 / 5$ [17]. Roosters are generally intended for sale to meet the financial needs of the household $[25,33]$.

The average number of eggs 11.93 per hen per laying in this study is comparable to Benin with 11.95 [36]. However, it is lower compared to the figures found in the DRC which recorded an average of 13.22 eggs per hen per laying [18], Vietnam with 12.73 eggs [49] and Côte d'Ivoire [64]; on the other hand it is much higher in Senegal with an average of 9 eggs per hen per laying [35]. Malnutrition and poor rearing conditions are said to be responsible for this low productivity [21].

The 91\% hatching rate found by this study is much higher than those reported in Vietnam (72.66\%) [49], Somalia (80\%) [65], Morocco (70\%) [66], Cameroon (82\%) [33], Guinea Conakry (71\%) [58] and Senegal (71.52\%) [35]. However, it is comparable to a study in the DRC which found an $88.8 \%$ outbreak rate [19] and in Burkina Faso which recorded up to $90 \%$ [67]. In spite of the poor farming, the local hen is reputed to be a good incubator.

The main use of the local chicken on the east coast of Madagascar is for live sale, followed by livestock renewal, self-consumption and socio-cultural utility. In Cameroon, Agbédé expressed that village poultry farming represents a significant source of income for rural households. However, part of the production is used for food and ritual ceremonies that play an important role in the life of the African population [33]. Ayssiwede and his colleagues in a similar study in Senegal confirm this, announcing that the sale of local chickens serves as a 'small cash' fund for poor households [68]. Income from livestock production would be used mainly for health, children's education, food and food security and other needs $[69,70]$. Thus, the results of this study are consistent with those of the few other African countries that confirm that the objective of local chicken farming is primarily for sale, consumption and socio-cultural purposes. The table $n^{\circ} 8$ below compares the percentages of these objectives obtained by this study with those of the few African countries. 
Table 8. Purpose of indigenous chicken farming in some African countries

\begin{tabular}{|c|c|c|c|c|}
\hline Countries & Sales $(\%)$ & Self-consumption (\%) & Socio-cultural (\%) & Author, year \\
\hline East Coast of Madagascar & 70 & 5 & 11 & Author, 2020 \\
\hline DRC & 90.28 & 35.83 & 28.06 & {$[18]$} \\
\hline Burkina Faso & 40 & 37 & 23 & [48] \\
\hline Benin & $80-90$ & $85-100$ & $40-60$ & {$[36]$} \\
\hline Ethiopia & 51.40 & 44.3 & 36.4 & [71] \\
\hline Cameroon & 18.5 & 26.5 & 23.9 & [32] \\
\hline Algeria & 51.92 & 30.76 & - & {$[29]$} \\
\hline Senegal & 53.3 & 38.9 & 8.2 & {$[47]$} \\
\hline
\end{tabular}

For chickens intended for sale, the price is variable but often depends on the weight of the animal. The male with a heavier weight is more expensive than the female with a lighter weight. Similarly, in Mali, the male sells for $450 \mathrm{~F}$ CFA and the female for 300 F CFA; in Senegal, in the Kolda region, the male is sold for 2,400 F CFA [35]; in Burkina Faso, the male costs 1,250 to 1,350 F CFA while the female costs 900 to 1,000 F CFA. Generally, among local breed chickens, the male is overweight than the female at the same age, and the chickens are sold live (live chicken) [72]. The price of male chickens on the east coast of Madagascar is similar to those in Algeria, which cost 820 DA or 7.32 euro, but cheaper for the female, which sells for 650 DA or 5.81 euro [29]. However, roosters from Madagascar are more expensive compared to those found in Cameroon at a price of 4.6 Euro, while their female chickens are expensive at 3.9 Euro [32].

The exploitation of local chickens can generate satisfactory profit margins for farmers. Farmers invest almost nothing, whereas the products obtained by local chickens are multiple: meat, sale of breeding stock, eggs [33]. The modest income from local poultry production helps the farmer to ensure certain purchases [29]. Traditional poultry farming could be an efficient way to fight poverty, to improve the food quality of the population, especially in developing countries, while increasing the family's lifestyle to meet multiple vital needs in rural areas [44]. Moreover, it also contributes to the economic situation of States through taxes at the time of transaction and marketing of local chickens [68].

\subsection{Problems in Traditional Poultry Farming}

Most of the problems that traditional family poultry farming suffers are of a technical nature and are related to the lack of control over health and reproduction. Bismwa and his collaborators have confirmed that the main cause of the decline in numbers remains epidemics $[18,33]$. Improving the productivity of traditional poultry farming can be achieved through a better knowledge of the diseases present in the area, a programme for the development of traditional poultry farming that involves both the foundation, research and agricultural development structures and the farmers [35]. It is essential to set up a supervision and technical training programme for poultry farmers [14].

In addition, the major problems faced by poultry traders are also financial. No financial support measures for these poultry farmers have been established by the Malagasy government. This difficulty is also encountered by poultry farmers in Togo, as access to credit is very complicated for them. As a result, the population's income is constantly decreasing, leading people to abandon meat consumption in favour of fish and the socio-economic impacts often caused by certain pathologies [30].

\section{Conclusions}

In conclusion, this study shows that local chicken farming on the East Coast of Madagascar is of economic, social and cultural importance to farmers of this area. The local breed of chicken remains and will remain the most important animal in the rural world. It is an industry that (i) can meet the family farming systems within the reach of rural Malagasy people, (ii) remains the most appreciated meat and can improve protein intake for them, and (iii) promotes social cohesion and maintains home customs and habits at home. Moreover, the farmers never think of abandoning local chicken farming despite the various technical and financial obstacles to family poultry farming in Fénérive-Est such as lack of control over reproduction, theft and transmittable diseases. All of that confirmed the hypothesis of this study but the rural exploitation faces various social, economic and especially technical challenges. Thus, its problems can be controlled with the support of the State by providing training for the breeders and facilitating access to agricultural credits to restart its activities. All this will be furthered by a scientific improvement strategy through selection or cross-breeding to improve production in terms of quality and quantity while maintaining the bird's genetic heritage.

\section{Acknowledgements}

We are grateful to the University of Toamasina, through 
its President Mr. ZAFITODY Conscient, for the financial support he granted us during the realization of this research. Our sincere thanks to Mr President. We would also like to thank the team of researcher lecturers from the UR ADI-Suds of ISTOM-Angers in France, led by the Director Research OSWALD Marc, having contributed in the improvement of this work.

\section{REFERENCES}

[1] J. N. Randriamoria. Système statistique agricole et alimentaire de Madagascar, rapport panorama $\mathrm{n}^{\circ} 1$, pp11-15, 2015 .

[2] C. Zafitody. Méthodes de prise de décision sur l'amélioration des exploitations agricoles : cas de la côte-est malgache, thèse de doctorat en sciences agronomiques, option agro-management, école supérieure des sciences agronomiques, université d'Antananarivo. 219 p, 2012.

[3] World Bank. Draft project appraisal document, Madagascar emergency food security and social protection project, world bank: Washington dc, 2013.

[4] FAO. Cadre de programmation pays 2014-2019, république de Madagascar, pp3-6, 2014.

[5] FAOSTAT. Développement de l'aviculture familiale enjeux, opportunités et contraintes, s.l.: documents de travail FAO production et santé animale no. 12. Rome, 2014.

[6] M. Rakotoarimalala. Aviculture familiale à Madagascar: productivité et performance de croissance du poulet de race locale dans la zone forestière de Moramanga (corridor forestier Analamay-Mantadia), mémoire de fin d'études en vue de l'obtention du diplôme d'ingénieur agronome, option élevage, école supérieure des sciences agronomiques, Antananarivo, 103p, 2016.

[7] M. Koko, O. F. Maminiaina, J. Ravaomanana, S. J. Rakotonindrina. Aviculture villageoise à Madagascar: productivité et performance de croissance, improving farmyard poultry production in Africa: interventions and their economic assessment. Vienne: aiea-tecd, pp 137-143, 2006.

[8] A. T. Andriamaroarison. Typologie de l'aviculture villageoise de Vatomandry face à la maladie de Newcastle, thèse pour l'obtention du diplôme d'état de docteur en médecine vétérinaire, faculté de médecine université d'Antananarivo, 120 p, 2017.

[9] Centre de recherche, d'études et d'appui à l'analyse économique à Madagascar (CREAM). Monographie de la Région Analanjirofo, Antananarivo, http://www.monograph iemada.com. 212 p, 2013.

[10] Commune rurale Ampasimbe Manantsatrana. Plan communal de développement d'Ampasimbe Manatsatrana, pp 3-12, 2015.

[11] Commune rurale Mahambo. Plan communal de développement de Mahambo, pp 5-12, 2015.

[12] Commune rurale Ambodimanga II. Plan communal de développement d'Ambodimanga II, pp 4-9, 2015.

[13] Région Analanjirofo. Plan régional de développement Analanjirofo, Madagascar fort, 91 p, 2015.

[14] J. C. Fotsa. Caractérisation des populations de poules locales (Gallus gallus) au Cameroun, thèse pour obtenir les grades de Docteur d'Agroparistech et de Doctor of phylosophy (Ph.D) de l'Universtié de Dschang, Caméroun, discipline : Génétique animale/Génétique animale et Systèmes de production, 301 p, 2008.

[15] N. Ferraton, I. Touzard. Comprendre l'agriculture familiale, diagnostic des systèmes de production, édition quae, presses agronomiques de Gembloux, 123p, 2009.

[16] H. F. A. Randriamandratondrakotonirina. Caractérisation de l'élevage de lapin dans la région d'amoron'i mania et incorporation de la spiruline «Spirulina platensis » comme complément alimentaire des jeunes lapins de race locale; thèse de doctorat en sciences agronomiques ; école doctorale Agriculture Elevage et Environnement, école supérieure des sciences agronomiques, Université d'Antananarivo, 190 p, 2019.

[17] O. C. Hien, B. Diarra, Y. Drabo, H. Boly, L. Sawadogo. Pratiques de l'aviculture traditionnelle par les différents groupes ethniques de la région des cascades au Burkina Faso, agronomie africaine 17 (3): 227-239 pp, 2005.

[18] N. P. Bisimwa, B. R. Ayagirwe, R. T. Lugamba, S. D. Wasso, B. Aksanti, B. E. Bisimwa. Le système de production de la poule locale contraint son développement au Sud-Kivu, Est de la République Démocratique du Congo; Journal of Applied Biosciences 135: pp 13821-13830, 2019. https://dx.doi.org/10.4314/jab.v135i1.8.

[19] Y. Mugumaarhahama, R. B. B. Ayagirwe, V. B. Mutwedu, J. M. Sadiki, P. Baenyi, A. C. Mushagalasu, E. B. Bisimwa. Caractérisation des systèmes de production de poule locale dans deux zones agro-écologiques du Sud-kivu (République Démocratique du Congo); livestock research for rural development 28 (1), pp 1-14, 2016, https://www.researchga te.net/publication/289210809.

[20] F. N. Ekue, K. D. Pone, M. J. Mafeni, A. N. Nfi, J. Njoya. Survey of the traditional poultry production system in the Bamenda area, Cameroon. International Atomic Energy Agency (IAEA): IAEA. Joint FAO/IAEA Division of Nuclear Techniques in Food and Agriculture, Animal Production and Health Section, Vienna (Austria); 205 p; ISBN 90-5782-094-3; pp 15-25, 2002.

[21] E. F. Guèye. Village egg and fowl meat production in Africa. World's Poultry Science Journal, 54(1), 73-86. doi:10.1079/WPS19980007, 1998.

[22] A. Barua, M. A. R. Howlider, Y. Yoshimura. Indigenous Naked Neck fowl of Bangladesh. World's Poultry Science Journal, 54, (Sept.1998): 279-286, 1998.

[23] J.M. Ndegwa, R. Mead, P. Norrish, P. W. Kimani, A.M. Wachira. The growth performance of indigenous Kenyan chickens fed diets containing different levels of protein during rearing, tropical animal health and production, 33; 441- 448, 2001

[24] E. F. Guèye. The role of family poultry in poverty alleviation, food security and the promotion of gender equality in rural Africa, Outlook on Agriculture 29(2): 129-136, 2000. 
[25] J. C. Fotsa, X. Rognon, M. Tixier-boichard, J. D. Ngou Ngoupayou, D. Poné Kamdem, Y. Manjeli, A. Bordas, exploitation de la poule locale (gallus gallus) en zone de foret humide du Cameroun, publié dans le bulletin de santé et de production animales en afrique (2007), 55, 59-73, 2007.

[26] P. R. Ralien. Situation actuelle de l'élevage de poulets de race locale aux environs d'Avaratr'ankatso, mémoire pour l'obtention du diplôme de licence en sciences agronomiques et environnementales, Mention Sciences Animales, école supérieure des sciences agronomiques. 56 p, 2017.

[27] J. G. Bell, T.M. Fotzo, A. Amara, G. Agbede. Proceedings of the international workshop, M'bour, Sonaiya (ed), 308, 2000 .

[28] E. Téleu Ngandeu, A. Ngatchou. Organisation des nations unies pour l'alimentation et l'agriculture, projet osro/glo/mul, $1,2006$.

[29] F. Z. Mahammi. Caractérisation phénotypiques et moléculaires des populations de poules locales (Gallus gallus domesticus) de l'ouest algérien. Thèse en vue d'obtention du diplôme de doctorat, faculté des sciences de la nature et de la vie, département de génétique moléculaire appliquée, Université des sciences et de la technologie d'Oran Mohamed Boudiaf, Algérie, 180p, 2015.

[30] FAO. Secteur avicole Togo, revues nationales de l'élevage de la division de la production et de la santé animales de la FAO, no. 9, Rome. ISBN 978-92-5-208763-2. 71p, 2015.

[31] F. Akouango, P. Bandtaba, C. Ngokaka. Croissance pondérale et productivité de la poule locale gallus domesticus en élevage fermier au Congo Brazaville. Animal genetic resources, 2010, 46, 61-65. DOI:10.1017/s2078633 610000706. 61-65pp, 2010.

[32] J. C. Fotsa, X. Rognon, M. Tixier-boichard, J.D. Ngou Ngoupayou, D. Poné Kamdem, Y. Manjeli, A. Bordas. Uses of local chickens (Gallus gallus) under the humid forest zone of Cameroon ; bulletin de santé et de production animales en afrique (2007), 55, pp 59-73, 2007.

[33] G. B. Agbédé, A. Téguia, Y. Manjeli. Enquête sur l'élevage traditionnel des volailles au Cameroun; tropicultura, 13, 1, 22-24; 1995,https://www.researchgate.net/publication/2862 79245.

[34] C. Ly, M. Savane, M. T. Seck, A. Faye. L'aviculture au sud du Sénégal, cahiers agricultures, 8 :123-125, 1999.

[35] E. Talaki. Aviculture traditionnelle dans la région de Kolda (Sénégal) : structure et productivité ; mémoire de fin d'étude pour l'obtention du diplôme de docteur vétérinaire, faculté de médecine et de pharmacie, Université Cheikh Anta Diop de Dakar, 132p, 2000.

[36] R. Chabi Toko. Caractérisation phénotypiques et gestion de la population de poulets locaux dans les communes de Dassa et de Toffo au Bénin, mémoire pour l'obtention du diplôme d'études approfondies (DEA), option: management des ressources animales, faculté des sciences agronomiques, université d'Abomey-Calavi, 74 p, 2008.

[37] S. K. Njenga, Productivity and socio-cultural aspects of local poultry phenotypes in coastal Kenya. M.sc.thesis. the royal veterinary and agricultural university, Copenhagen, Denmark, 31 p, 2005.
[38] H. H. Mogesse. Phenotypic and genetic characterization of indigenous chicken populations in northwest ethiopia. $\mathrm{PhD}$ thesis. University of the free state, bloemfontein, south africa, 186 p, 2005.

[39] H. F. A Randriamandratondrakotonirina, H. D. Razaivaovololoniaina, M. V. Falinirina, V. Razafintsalama, J. N. Rakotozandriny. The increasing of peasant's income farmers in Amoron'i Mania region by ameliorating the production system of rabbit ; universal journal of agricultural research 3(5): 155-164, 2015, doi: 10.13189/ujar.2015.0305 03, http://www.hrpub.org.

[40] L. Y. Mopate, A. Maho. Caractéristiques et productivité des élevages familiaux de poulets villageois au Sud du Tchad, revue africaine de santé et de production animales (Raspa), vol, 3 (1) : pp 41-46, 2005.

[41] M. Koko, O. F. Maminiaina, J. Ravaomanana, S. J. Rakotonindrina. Aviculture villageoise à madagascar: productivité et situation épidémiologique, in characteristics and parameters of family poultry production in Africa, $\mathrm{pp}$ 47-63, 2002.

[42] M. Koko, O.F. Maminiaina, J. Ravaomanana, S.J Rakotonindrina. Aviculture villlageoise à Madagascar: productivité et performance de croissance. DOI: 10.13140/rg.2.1.2569.4560, pp 137-147, 2015 https://www. researchgate.net/publication/280533931.

[43] A.T. Andriamaroarison. Aviculture villageoise face à la maladie de Newcastle dans les communes de Vatomandry ; thèse pour obtenir le grade de docteur en médecine vétérinaire ; faculté de médecine, Université d'Antananarivo, $120 \mathrm{p}, 2017$.

[44] J. C. Fotsa, D. K. Poné, Y. Manjeli, J. M. Mafeni. Etude des systèmes d'élevage et description phénotypique des poules locales (gallus gallus) en milieu rural de la zone forestière du Cameroun, doi: 10.4314/cjas.v3i1.48355, 2009https://www .researchgate.net/publication/272336593.

[45] P. N. Mbugua. Rural small-holder poultry production in Kenya, C.T.A., seminar proceedings, vol. 2, 9-13 oct.1990, Thessaloniki, Greece. 41-47pp, 1990.

[46] E. F. Guèye. Employment and income generation through family poultry in low-income food-deficit countries, World's Poultry Science Journal, 58:4, 541-557, DOI: 10.1079/WPS20020039, 2002.

[47] INFPD/FAO/IFAD. Opportunités des programmes de sélection avicole pour la production familiale dans les pays en voie de développement : l'oiseau pour le pauvre, rapport d'une conférence électronique tenue 24 janvier-18 février 2011. 129 p, 2011.

[48] S. Pousga, H. Boly. Synthèse des travaux de recherche en aviculture au Burkina Faso; aviculture familiale FAO, vol.18, no.1\&2, pp 28-35, 2010.

[49] D. Nguyen Van. Caractérisation de la race de poule ho dans sa région d'origine: province de Bac Ninh (Vietnam), Mémoire présenté en vue de l'obtention du grade de formation doctorale, Université de Liège, 31p, 2016.

[50] S. Pousga, H. Boly, J. E. Lindberg, B. Ogle. Scavenging chickens in Burkina Faso: effect of season, location and breed on feed and nutrient intake. Tropical animal health and production 37: pp 623-634, 2005. 
[51] S. R. Kondombo. Improvement of village chicken production in a mixed (chicken-ram) farming system. $\mathrm{PhD}$. thesis, wageningen institute of animal science, wageningen university, the Netherlands, 2005.

[52] F. Z. Mahammi, S. B. S. Gaouar, N. Tabet-Aoul, M. Tixier-Boichard, N. Saïd-Mehtar. Caractéristiques morpho-biométriques et systèmes d'élevage des poules locales en Algérie occidentale (Oranie), cah agric, vol. 23, $\mathrm{n}^{\circ} 6$, novembre-décembre 2014; doi: 10.1684/agr.2014.0722, pp 382-392, 2014.

[53] A. D. El-yuguda, S. S. Baba, U. I. Ibrahim, F. Brisibe. Maladie de newcastle et maladie de gumboro chez les poulets villageois dans l'etat de Borno (Nigeria), aviculture familiale vol.18, $\mathrm{n}^{\circ} 1 \& 2.18-27 \mathrm{pp}, 2010$.

[54] N. Moula, N. Detiffe, F. Farnir, N. Antoine, P. Leroy. Aviculture familiale au Bas-Congo, République Démocratique du Congo (RDC), Livestock research for rural development 24 (5): 2012. http://www.lrrd.org/lrrd24/5/mo ul24074.htm.

[55] H. Boussini. Contribution a l'étude des facteurs de mortalité des pintadeaux au Burkina Faso, these de medecine veterinaire, eismv, Dakar, Senegal, 1995.

[56] R. Bessin, A. M. G. Belem, H. Boussini, Z. Compaore, Y. Kabore, M.A. Dembele. Enquête sur les causes de mortalité des pintadeaux au Burkina Faso, revue d'élevage et de médecine vétérinaire des pays tropicaux, 51, 87-93, 1998.

[57] A. O. S. Kounta, La réalité de l'aviculture villageoise au Mali, tropicultura, 9, 2, pp 86-89, 1991.

[58] M. Mourad, A. S. Bah, G. Gbanamou. Evaluation de la productivité et de la mortalité de la poule locale sur le plateau de Sankaran, Fanarah, (Guinée), rev. eiev. méd. vét. pays trop. 50 (4): 343-349pp:1997.http://remvt.cirad.fr/cd/e mvt97_4.pdf.

[59] A. Buldgen, F. Detimmerman, B. Sall, R. Compere. Etude des paramètres démographiques et zootechniques de la poule locale du bassin arachidier Sénégalais. rév. elev. méd. vét. pays trop., 45 (3-4) : pp 341-347, 1992.

[60] H. A. Andriamboahangy. Aviculture villageoise: performance de productivité de poule locale cas de district de Manandriana. Thèse pour obtenir le grade de docteur en médecine vétérinaire, faculté de la médecine, Université d'Antananarivo. 99p, 2017.

[61] G. N. Ndeledje. Amélioration génétique de la poule locale au Sénégal par croisement avec les races exotiques : résultats primaires, thèse : médecine vétérinaire: Dakar, 96p, 2000.
[62] D. Villate. Les maladies des volailles, l'appareil digestifs; INRA. 345 p, 2001.

[63] FAO. Secteur avicole Togo, revues nationales de l'élevage de la division de la production et de la santé animales de la FAO. no. 9. Rome. 71 p, 2015.

[64] K. E. Kouadio, B. J. Kouao, A. Fantodj, A. Yapi, L. Yrebe. Influence du système d'élevage sur la mortalité des poulets locaux, cnra, j. appl. biosci. 32: pp 2020-2026, 2010.

[65] A. Lul Said. Small holder rural poultry production in the somalie démocratic republic. C.T.A, seminar proceedings, vol.2, 9-13 oct. 1990, Thessaionki, Greece. 207-214 pp, 1990.

[66] M. El Houadi. Rapport sur la production avicole et problèmes liés aux élevages traditionnels au maroc, C.T.A, seminar proceedings, vol.2, 9-13 oct. 1990. Thessaionki, Greece. 207-214 pp, 1990.

[67] D. Bourzart, M. Saunders. Internationnal methods of poultry production in burkina faso. in proceedings, cta seminar, 3rd international symposium on poultry production in hot climates, hameln, germany, 1990.

[68] S. B. Ayssiwede, A. Dieng, M. R. B. Houinato, C. A. A. M. Chrysostome, I. Issay, H. Jean-luc, A. Missouhou. Elevage des poulets traditionnels ou indigènes au Sénégal et en afrique subsaharienne: état des lieux et contrainte ; in annales de médecine vétérinaire, 158:101-117. Université de liège. 2013.

[69] S. R. Kondombo, A. J. Nianogo, R. P. Kwakkel, H. M. Y. Udo, M. Slingerland. Comparative analysis of village chicken production in two farming systems in Burkina Faso; tropical animal health and production 35 (6): 563-574. 2003.

[70] D. Damiba. Résultats et impacts de l'usage de la volaille comme outils pour le développement et la mobilisation du revenu dans la province du boulgou, Burkina Faso. 10p, 2005 .

[71] M. Fisseha. Studies on production and marketing systems of local chicken ecotypes in Bure Woreda, North-west Amhara regional state, Ethiopia, in. msc thesis, Hawassa University, Ethiopia, City. 2009.

[72] T. C. eambou, Y. Manjeli, J. Tchoumboue, A. Teguia, R. N. Irome. Caractérisation morphobiométrique des ressources génétiques de poules locales des hautes terres de l'ouest Cameroun, livestock research for rural development, 19 (8). 2007. http://www.cipav.org.co/lrrd//rrd19/8/keam19107.ht $\mathrm{m}$ 